\title{
Post-Kalkınmacılık Teorisi Işığında Bölgesel Kalkınmacılık Krizi
}

\section{Crises of Regional Development in the Context of Post-Development Theory}

Ahmet Efe ${ }^{\text {a,* }}$

a Dr, CISA, CRISC, PMP, COBITF, İç Denetçi, Ankara Kalkınma Ajansı, Ankara/Türkiye.

ORCID: 0000-0002-2691-7517

\begin{tabular}{l} 
MAKALE BİLGİSİ \\
\hline Makale Geçmişi: \\
Başvuru tarihi: 09 Eylül 2019 \\
Düzeltme tarihi: 20 Ekim 2020 \\
Kabul tarihi: 27 Ekim 2020 \\
\hline Anahtar Kelimeler: \\
Yeni bölgeselcilik, \\
Kalkınma Ajansları, \\
Bağımlılı Teorisi, \\
Neoliberalizm, \\
Kalkınma sonrası, \\
Paradigma Krizi
\end{tabular}

\section{A R T I C L E I NFO}

\section{Article history:}

Received 09 September 2019

Received in revised form 20 October 2020

Accepted 27 October 2020

\section{Keywords:}

New Regionalism,

Development Agencies,

Dependency Theory,

Neoliberalism,

Post-development,

Paradigm Crisis
ÖZ

Az gelişmiş ülkeleri gelişmiş batıya kıyasen geliştirmeye çalışan Modernizm teorisi, 1970'lerde ABD ekonomisinde enflasyon ve durgunluğun birlikte yaşanması olan stagflasyon sorununun başlaması, kalkınma projeleri ile harcamacı devlet politikalarıyla gelişmeye çalışan üçüncü dünya ülkelerinin aşırı borçlanması ve petrol krizinin meydana gelmesiyle birlikte değişime uğradı. Buradaki suçlunun "government failure" olarak adlandırılan devletçi uygulamaların başarısızlığı olduğu kabul edilmeye başlanarak neoliberal, postmodern ve postkalkınmacı yaklaşımlar giderek güçlendi. Postkalkınmacı teori, postyapısalcı yaklaşımla "kalkınma" nosyonunun eleştirisini yaptığından dolayı kurumsal gelişimin reddini ortaya koymaktadır. Bu çalışmada, Türkiye'deki Bölgesel Kalkınma Ajanslarındaki kurumsal sorunlar Kalkınma Teorisindeki kuramsal ve kavramsal değişimlerle ilişkilendirilmektedir. Ayrıca, sorun çözücü araştırma yöntemleriyle bir takım analiz ve değerlendirmeler yapılmaktadır. Çalışmanın iddiası, postkalkınmacı teorinin temel varsayımları doğru olsa bile, aşırı genellemekten kaçınılarak ulusal, bölgesel ve yerel ihtiyaçlara göre yapılabilecek kurumsal yapılandırmaların buna istisna teşkil edebileceğidir.

\section{A B S T R A C T}

The theory of Modernism, which tried to develop underdeveloped countries compared to the developed west, was changed with the beginning of the stagflation problem, which was the coexistence of inflation and stagnation in the US economy in the 1970s, the excessive borrowing of third world countries trying to develop with development projects and spending government policies, and the occurrence of the oil crisis. Neoliberal, postmodern and post-developmentist approaches gradually became stronger, as the culprit here was accepted as the failure of statist practices called "government failure". Post-developmentist theory reveals the rejection of institutional development as it criticizes the notion of "development" with the poststructuralist approach. In this study, institutional problems in the Regional Development Agencies in Turkey is associated with theoretical and conceptual changes in development theory. In addition, some analyzes and evaluations are made with problem-solving research methods. The claim of the study is that even if the basic assumptions of post-development theory are correct, institutional configurations that can be made according to national, regional and local needs may be an exception, avoiding over-generalization.

\section{Giriş}

İkinci Dünya savaşının askeri düşmanlıkları sona erdiğinde 1949 yılında ABD Başkanı Hary Truman tüm Dünya için "fair deal" ismi verilen adil davranış ve hayır işlerine başladıklarını duyurmuşlardı. Üçüncü dünya ülkelerde yaşanan miskinlik ve yaşam mücadelesinden kaynaklanan sorunların çözüleceği de vaat edilmişti. Bu kapsamda da
Asya ve Afrika'daki sömürgeler 1950-60'larda bağımsızlıklarına kavuşturularak Birleşmiş Milletlere üye pek çok ulus devlet inşa edilmişti. Bu şekilde kapitalist sistemle tam entegre olmuş modern ulus devletlerin kurulması da hızlandırılmış olacaktı. Modernizm teorileriyle birlikte Birleşmiş Milletler 1960’ lı yılları “ $U N$ Development Decade" adıyla anılacak şekilde kalkınma

\footnotetext{
* Sorumlu yazar/Corresponding author.

e-posta: icsiacag@gmail.com
} 
yılları olarak ilan etmişti. $\mathrm{Bu}$ kapsamda gelişmemiş ulusların kendi kendine yeter sürdürülebilir ekonomik büyümelerine doğru onları hılandıracak tedbirleri destekleyecek şekilde kaynaklar seferber edilmişti. Doğubatı mücadelesine ek olarak güney-kuzey sorunu da gelişmişlik farkı olarak ortaya çıktığından dolayı Dünya için barış ve refahı tehdit eden bir unsur olarak görülüyordu (Litonjua, 2012, s. 27).

Modernizm teorisi, modern devlet oluşturma çabalarının yapılandırılmasını sağlanmıştır. Az gelişmiş ülkelerin sorunlarını analiz edip açıklayan ilk teorik yaklaşım modernizm olarak ortaya çıkmıştır. Ancak modernizm, batı ülkelerinin 16.yy.'dan sonra tecrübe ettiği tarım toplumundan endüstri toplumuna geçiş sürecini esas alarak gelenekselden moderne doğru altta gelişmekte olan fakir ülkelerden başlayarak tepedeki model batı toplumlarına doğru tüm ülkelerin sıralamasını yapmıştır. Dolayısıyla gelişmekte olan toplumları yardıma muhtaç geleneksel toplum olarak kategorize etmiş ve batılı toplum olma yönünde harekete geçirilmeleri gerekliliğini ortaya koymuştur.

Modernizmin ana fikri, Amerikan sosyolojisi alanında baskın bir kişilik olan Talcott Parsons tarafından "yapısal ayrıştırma, fonksiyonel özelleşme ve kültürel sekülerleşme süreçleri" olarak detaylandırılmıştır. Modernizmin ekonomi alanında yansıması olarak gelişmekte olan ülkelerin takip etmeleri gereken beş kategori Walt Rostow tarafından, politik alanda yansımasını girdi-çıktı modeliyle "karşılaştırmalı politika bilimine fonksiyonel yaklaşım" olarak göstermiştir. En sonunda da modernizasyon teorisi Keynezyen ekonominin de etkisiyle gelişmekte olan ülkelere kalkınma programları ve projeleriyle hibe verilmesi ve bu yolla oluşturulacak talep artışının aynı zamanda batı ülkelerinin ekonomilerini de ayakta tutacağı savunulmaya başlandı. (Litonjua, 2012, s. 27-28).

Dolayısıyla modernizm teorisi de 1970'lerde ABD ekonomisinde enflasyon ve durgunluğun birlikte yaşanması olan stagflasyon başlamasıyla, kalkınma projeleriyle harcamacı devlet politikalarıyla gelişmeye çalışan üçüncü dünya ülkelerinin aşırı borçlanmasıyla ve ardından petrol krizinin meydana gelmesiyle değişime uğradi. $\mathrm{Bu}$ vesileyle suçlunun hükümet ve devletçi uygulamalar olduğu kabul edilmeye başlanarak neoliberal, post modern ve postkalkınmacı yaklaşımlar baş aktör göstermeye başlamıştır.

Kamu yönetimi alanyazınında, materyalist üretim biçimleri (mode of production) kapsamindaki sinıflandırma bağlamında konulara yaklaşıldığında, genel olarak kapitalist üretim biçiminin, feodaliteden sıyrılmasından itibaren üç sermaye birikimi aşamasında geçtiği kabul edilebilmektedir. 1776/1789-1939 dönemi için üretim biçiminin kuruluşu ve liberal birikim aşaması; 1945-1980 dönemi için fordist sermaye birikim aşaması; 1980 ve sonrası için de neo-liberal/post-fordist sermaye birikim aşaması olduğu ileri sürülmektedir (Aslan, 2006). Bu şekilde dönemsel genellemeler kuşkusuz her toplumda ve koşulda mutlak doğruluğu olmamakla birlikte genel anlamda, küresel ölçekte ve tarihi düzlemde yaklaşık ve ortalama durumsallığı yansitabilen bir genelleme olarak kabul edilebilir.
Yeni-neo-post önekli paradigmaların en temel olan kesişim noktalarının, ekonomik ve teknolojik gelişmelerin sonucu olarak iletişim ve üretim tekniklerinin kültürel ve ekonomik etkileşimi arttırarak yeni paradigmaların doğuşuyla açıklanabileceği söylenebilir. Buna kapitalizmin kendisini yeniden üretmesinin tanımlama sürecindeki tartışmaları da denilebilir. Ekonomik ve kültürel dinamiklerin yoğunlaşmasının bir sonucu olarak Dünyadaki küresel bilgi ve eğlence bakışıyla yeni zorluklara karşı direnmeye yeni tepkileri de doğurabilmektedir (Bartling, 2004, s. 135).

Küreselleşme ile birlikte daha fazla yoğunlaşan merkezçevre ilişkileri de analiz edilerek özellikle büyük kalkınma programlarının başarısızlığının akabinde 1970'li yıllarda "dependency theory" ad1 altında "băğmlılık teorisi" de alternatif olarak geliştirilmiştir. Buna göre kalkınma program ve projelerinin sonucunda arzulanan sosyal dönüşüm ve üretkenlik sağlanamamış tam tersine zenginler daha zengin ve fakirler daha fakir hale gelmişlerdir. Dolayısıyla az gelişmişliğin nedeni de modernizm teorisindeki gibi onların gelenekselliği değil, tam tersine merkez ve çevre arasındaki baskınlık-bağımlılık ilişkisi olduğu ortaya konulmuştur. Bağımlılık teorisine göre merkez ülkeler ileri düzeyde gelişmiş kuzey Amerika, batı Avrupa, Japonya, Avustralya, Yeni Zellanda' dan oluşurken çevre ise Latin Amerika, Asya, Afrika ülkelerinden oluşmaktadır. Buna göre merkez ülkeleri, ulusüstü şirketler, uluslararası kurumlar ve finansal sistem aracılığıyla çevre ülkelerinin işgücünü ve doğal kaynaklarını sömürmekte ve onları politik ve sosyal yaşamına da müdahalede bulunmaktadır (Dobren'kov \& Rakhmanov, 2014).

"Kalkınma" nosyonu, fayda ve kullanışlılı̆̆ının kesinliğine dair delillerin mevcut olmamasından dolayı son yıllarda tartışmalara konu edilmiştir. Kalkınma, kuralları ve uygulamalarıyla özelleştirilmiş olması ve yararlanıcıların belirlenmiş çıkarlarına göre organize edilmiş olması durumunda yararlı olabilir (Andrews \& Bawa, 2014).

Post-kalkınmacı teori, post-yapısalcı yaklaşımla "kalkınma" nosyonunun eleştirisini yaptığından dolayı kurumsal gelişimin kökten reddini ortaya koyabilmektedir. Foucault tarafindan ortaya konulan yaklaşımda postkalkınmacılığa göre, "kalkınma" nosyonunun çözmek amacıyla ifade ettiği sorunları çözmekten ziyade daha çok onları yapılandıran monolitik ve hegemonik bir yaklaşım olduğu ifade edilmektedir (Lie, 2008).

\section{Araştırma Problemi ve Metot}

Kalkınma Ajansları üzerinde yapılan inceleme sonucunda DDK tarafından tespit edilmiş bulunan 43 sorundan iki adedinin araştırma problemimizle doğrudan ilişkili olabileceği değerlendirilmiştir. Anılan raporda kapsamlı bir şekilde incelemeye alınan sorunlardan anlaşıldığı kadarıyla bölgesel kalkınmacılık sistemi ve onun uygulama birimi olan KA politika ve uygulamalarında krize girmiştir. $\mathrm{Bu}$ durumun kavramsal ve kuramsal düzlemde incelenmesi gerekmektedir. Benzer sorunlar daha sonraki yıllarda Sayıştay Genel Değerlendirme Raporlarında da tekrar edegelen hususlar olarak kaydedilmiştir. $\mathrm{Bu}$ sorunların temelinde kuramsal ve 
paradigmatik değerlendirmeler yapılmamış olması bu araştırmada sorunsal olarak kabul edilebilmiştir.

Paradigma teorisi ve bilimsel krizler teorisi ile meşhur olan Thomas Kuhn'un ünlü yapıt1 "The Structure of Scientific Revolution" (Kuhn T. , 1962) ile tartışma alanına giren paradigma kavramı oldukça esnek bir çerçevede kullanılmıştır. Kuhn, bilim dünyası tarafından kabullenilen inançlar ve kanaatler bütününe veya sorunların inceleme metodolojisi hususunda üzerinde hemfikir olunan gelenek ve tanımlamalara "paradigma" adını vermiştir. Kuhn'a göre bilimsel sorgulamanın temeli olarak bir konu hakkında bilim adamlarınca ortaya konulan modelin içinde paradigma kavramı yatmaktadır. Kuhn'a göre; paradigma, bir bilimsel alanda üzerinde çalışılan problemlerin toplamı, kabullenilen teori ve modeller, uygulanan nicel, nitel ve deneysel yöntemler ile elde edilen sonuçların değerlendirilmesinde kullanılan sonuçlardan oluşmaktadır. Bölgesel kalkınmacılık ile ilgili olarak bir paradigma krizi olup olmadığının araştırma problemi çerçevesinde ortaya konulmasının olanaklı olup olmadığ 1 da incelenmektedir. Dolayısıyla bölgesel kalkınmacılık açısından paradigma teorisi kapsamında bilimsel kriz olup olmadığı noktasında analizlerin yapılması önem arz etmektedir.

Şekil 1. Bilimsel Krizden Çıkış ve Yeni Paradigma Oluşumu Döngüsü

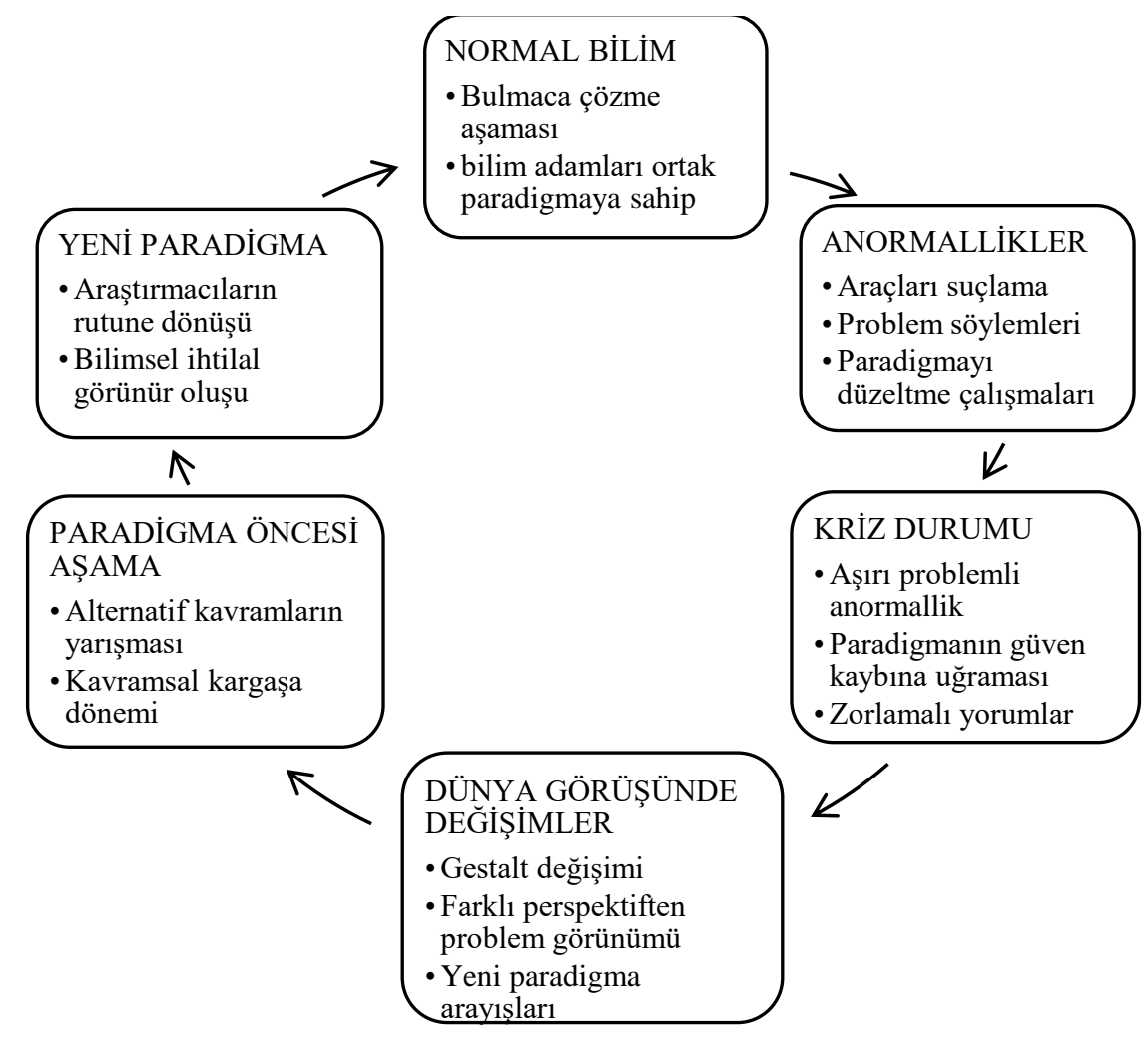

Kaynak: (Kuhn, 1962)'dan esinlenen araştırmacı tarafindan oluşturulmuştur.

Bölgesel kalkınmacılık açısından bakıldığında, verilen hibelerin özel sektörün daha da güçlenmesi ve piyasa aktörlerinin rekabetçilik ve yenilikçilik kabiliyetlerini güçlendirmeye odaklanıldığından dolayı bölgesel gelişme kapsamında yapılan uygulamaların neoliberal ve yeni kamu yönetimi anlayışını yansıttı̆̆ı söylenebilir. Ancak aynı zamanda kamu kaynaklarının piyasaya aktarılarak toplam talep oluşturulması noktasında genişletici maliye politikası uygulamaları kapsamında da değerlendirilebilmesinden dolayı keynezyen uygulamalarla da örtüşebilmektedir. Bu nedenle de yeni-neo-post dayanaklı politika ve uygulamaların çakışmasından ve postkalkınmacılık yaklaşımıyla reddedilmiş olmasından dolayı yeni bölgeselcilik ve yeni bölgesel kalkınmacılığın paradigma krizini yaşadığı ve yeni bir dönüşümü gösterebildiği söylenebilir.

Türkiye'de Devlet Planlama Teşkilatı tarafından başlatılmış olan kalkınmacıllk hareketini daha sonra onun yerine kurulan Kalkınma Bakanlığının (KB) devralması ve akabinde 2018 yılında bu bakanlığın da kapatılarak kalkınmacı yaklaşımın temsilcileri olan 26 ajans Sanayi ve Teknoloji Bakanlığına devredilmiştir. Ancak kalkınmacılık paradigmasının sanayi ve teknolojiye bağlı kılınması bu anlamda yeni bir paradigma krizinin ortaya çıktığını göstermektedir. Bu durumun paradigma teorisi bağlamında tahlil edilerek Türkiye koşullarında ve KA özelinde mevcut sorunlardan çıkış yolunun paradigma çerçevesinde çözümlenmesi gerekmektedir.

Araştırma konusu üzerinde veri tabanında literatür analizi yapılmıştır. Ebsco veri tabanında "post-development" olarak yapilan aramada 340 adet, "post development theory" olarak yapilan aramada 160 adet ve "development discourse" olarak yapılan aramada ise 580 yayın olduğu tespit edilmiştir. Türkçe literatürdeki yayınları tespit etmek amaciyla "post-kalkınmacılık", "post kalkınmacılı teorisi" "kalkınmacı söylem" ve "kalkınmacılık söylemi" olarak yapılan aramada hiçbir yayın olmadığı tespit edilmiştir. Bu anlamda araştırma yaptığımız alanda yeterli kadar yabancı literatür bulunmasına rağmen Türkçe literatürün henüz oluşmamış olması nedeniyle çalışmamızın ilk olma 
niteliğinden dolayı Türkçe literatüre ciddi katkıda bulunacağı söylenebilir.

$\mathrm{Bu}$ çalışmada paradigma teorisi çerçevesinde bölgesel kalkınmacılığı etkileyen yeni yaklaşımların kavramsal, teorik ve uygulama analizi yapılmaktadır. Temel yaklaşım postkalkınmacılık üzerinden bölgesel kalkınma yaklaşımının kritiğini yapmaktır.

İktisat ve kamu yönetimi disiplinlerinin kesişim alanında kalan çalışmamızda, bu yeni teori ve yaklaşımlardan araştırma konusu kapsamında kısaca bahsedilerek kalkınma teorileriyle ilişkili bir şekilde özellikle post-bürokrasi ile post-kalkınmacı söylemler üzerinde bazı teorik ve kavramsal analizler de yapılacaktır. $\mathrm{Bu}$ bağlamda betimleyici, ilişki arayıcı ve çözümleyici bir metodoloji benimsenmiştir.

Çalışmada ayrıca paradigmanın bilimsel kriz durumunda olup olmadığına dair tespit ve projeksiyon da yapılmaya çalışılmaktadır. Araştırmamızın iddiası yeni bölgesel kalkınmacılık paradigmasının krizde olduğudur. $\mathrm{Bu}$ çerçevede araştırma sorularımız aşağıdaki şekilde belirlenmiştir:

- Post Kalkınmacılı (kalkınma sonrasi) teorisi günümüz kalkınmacılık dinamiklerindeki sorunlara çözüm getirme noktasında eksiklikleri var mı?

- Post kalkınmacılık teorisiyle KA ve bölgesel kalkınma sorunları çözülebilir mi?

\section{Postkalkınmacılık (Post-Development)}

Postmodern teori, kalkınma çalışmalarına 1980’ li yıllardan sonra girmiştir. Kurumsal kalkınmanın kavramsal ve uygulama alanının post-yapısalcı anlayışla eleştirisi olarak bilinen post-kalkınmacılık, özünde Foucault'un güç-bilgi formasyonlarını "söylem" olarak yeniden kavramsallaştırması üzerinde devam etmektedir. postkalkınmacılığın önemli fikri "kalkınma söylemi üzerinde birinci dünyanın bilgi ve gücünü üçüncü dünya üzerinde şekillendirme" olarak ifade edilebilir (Lie, 2008).

Postmodernizm ve postyapısalcılıktan ciddi bir şekilde etkilendiği anlaşılan postkalkınmacılık üzerinde de bazı tartışmalar halen devam etmekle birlikte, artık günümüzde kalkınmacılık; sağlıklı beslenme, eğitim ve kişisel otonomiye yansıyan yükselen gelir düzeyinden anlaşılan kaliteli yaşam standartlarının yükseltilmesi olarak anlaşılmaktadır. $\mathrm{Bu}$ nedenle de teorisyenler kalkınmayı ölçerlerken Dünya Bankasının ekonomik göstergelerine dayanan istatistiklerini mi, Birleşmiş Milletler Kalkınma Programının İnsan Gelişim İndeksini mi kullanacakları konusunda farklı görüşlere sahiptirler. Fakat hepsi de kalkınmanın objektif bir şekilde teyit edilemeyeceği ve istenilemeyeceği konusunda hemfikirdirler (Rapley, 2004).

Postkalkınmacı yaklaşımda toplumsal kalkınma sadece yaşam standartlarındaki gelişime bağlanmamakta aynı zamanda gayr-i resmi sektörler de dikkate alınmaktadır. Bu anlamda kayıt dışı faaliyetler de kalkınmayı etkileyen unsurlar içerisine dâhil edilebilmektedir. Postkalkınmacıların üzerinde durduğu diğer bir husus da insan gelişiminin kendisi değil insanın kontrol ve yönlendirmesidir. Özellikle resmi ve kontrol kapsamındaki alana doğru insanların sevk ve teşvik edilmesi önem arz etmektedir (Rapley, 2004, s. 352).

Post-kalkınmacıllk teorisi, tekçi ve uyumlu bir teorik çerçeve sunmamaktadır. Daha doğrusu hala yeniden düşünülmekte ve tutarlı hale getirilmeye çalışılmaktadır. Bazen klasik kalkınma teorisinin, politikalarının ve uygulamalarının eleştirisiyle başlar ve biter. Sıkça da modern çağ öncesi için gerçekçi olmayan bir nostaljiyi takınır. En kötüsü de solcu anarşist veya aşırı sağcı popülist olmasıdır. Çoğu durumlarda Michel Foucault'un "güç ve söylem"inin ve Edward Said'in oryantalizmi ve emperyalizmi ve aynı zamanda postmodernizm, postyapısalcılık, postkolonial çalışmaları, yapı bozumu, kültürel, feminist ve çevreci çalışmalarından düşünceler postkalkınmacılığın genel görünümünü ve etkisini oluşturmaktadır. (Litonjua, 2012, s. 42)

Postkalkınmacıların klasik ve modern kalkınmacılığa karşı çıkışlarının nedenleri ve varsayımları aşağıdaki şekilde siralanabilmektedir. $\mathrm{Bu}$ siralamaya göre postkalkınmacıların söylemleri gerekçeleriyle birlikte ortaya konulmaktadır. Bunun yanı sıra Türkiye uygulamasında KA sistematiğindeki yansıması ve mevcut durum veri olarak alındığında ne tür düzenleme ve uygulama değişiklikleri yapılması gerektiği hakkında da değerlendirmeler yapılmaktadır.

\subsection{Postmodern Kalkınma Söylemi "Development Discourse" ve Biyogüç "Biopower"}

Michel Foucault tarafindan ortaya atılan bu söyleme göre; dil ve tanımlamalar, aynı zamanda güç ilişkilerine göre yapılır ve güç dengelerini gösterir. Buna göre, güçlü olan tanımlamayı yapar ve kuralı koyar. Ortaçağdaki bilim adamlarının deli ilan edilmesi gibi, kolonici ve kolonicilik sonrası akımlar ile oriyental söylemler gelişmiş batının söylemleri olup, kendi güç ilişkilerine ve çıkarlarının optimizasyonuna göre tanımlamalar yapılmıştır. Oriyental olan merkez batının uzantısı olduğu gibi, oriyentalizm de, farklılık ve politik temsil ile ilgili soruları gündeme getirir. Çünkü oriyentalist kültürel temsil, sadece kelimenin 1stılahında, düşüncede ve görüntüde değildir. Oryentalizm'de doğu; ilkel, kaba, batıl inançlı ve gizemli olarak gösterilmiştir. Çünkü batı ise ona göre kalkınmış, medeni, merkezi, bilimsel ve ilericidir. Işığın karanlığın derecesine göre belirginleşmesi gibi, doğunun özsel temsili, karşıt ve üstün olan batının öz imajını güçlendirmiştir. Oryentalist özsel söylem, batıya onları kullanma, yönetme ve suiistimal etme hakkını teyit eder ve meşru kılar (Litonjua, 2012, s. 44). Bu nedenle de kalkınmacılık aslında batının güç dengelerini korumaya yönelik bir tanımlamasıdır.

"Kalkınma", bir düşünme biçimi olarak ve uygulama kaynağı olarak her yerde kullanılan bir realite haline gelmiştir. Fakir ülkeler, kaçınılmaz olarak görülen ve gelişmiş batının kontrollerini güvenceye alan sonsuz sayıdaki müdahale, proje ve programların hedefi haline gelmişlerdir. $\mathrm{Bu}$ ülkelerin nüfusları, sermaye birikimi ilerlemesi, doğal kaynakları, tarım ve ticaretleri, idareleri ve kültürel değerleri dâhil olmak üzere sosyal ve ekonomik hayatları için önemli olan her şeyleri uzmanlar tarafından bu iş için geliştirilmiş olan tekniklerle hesabı yapılan özneleri ve aynı zamanda yeni oluşturulmuş kurumların 
müdahalesi için geniş bir nesneler seti haline gelmişti. (Litonjua, 2012, s. 45) $\mathrm{Bu}$ müdahale ve projelerle az gelişmiş ülkelerin kendi iç pazar dinamikleri bozulduğundan dolayı kendi dinamikleri olan üretici güçleri ve bilgi birikimi oluşamadan sürekli bir diş bağımlılık ve yardıma muhtaçlık ilişkisi geliştirilmiştir.

Foucault tarafından geliştirilen biyogüç "biopower" analizleri de, toplumların bir biyolojik varlık gibi olduğunu, içeriden biyolojik gelişim gibi iç organların gelişimine dayanan dâhili istek ve büyümeyle kalkınmanın olanaklı olabildiğini ifade etmektedir. Buna göre merkez kapitalist ülkeler kendi biyolojik gelişimlerini kolonileştirme hareketleri ile elde ettikleri bilgi ve güç sayesinde sağlayabilmişlerdir. Ancak kolonicilik sonrası toplumlarda bu güç henüz meydana gelememektedir. Kolonicilik zamanındaki üstünlüklerini de doğrudan baskı ve kaba güç yerine "kalkınma" söylemi üzerinde kendi biyolojik gelişimlerine hizmet edecek şekilde mobilize etmelerine aracılık etmesidir. Ulus devletlerin inşası, refah devleti, modern devlet, kalkınma planları ve kalkınan toplumlarla ilgili politikalar Dünya Bankası gibi ulusüstü kurumlar tarafından üçüncü dünya ülkelerine kabul ettirilerek merkez kapitalist ülkelerin çıkarları korunmaktadır (Brigg, 2002).

\subsection{Kök Organizasyonlar}

Kalkınma, epistemolojik bir problemle başladığından dolayı bunun çözümü de metodolojik olmalıdır. Buna göre bilgi akışı aşağıdan yukarıya doğru, tarihin içinden, tarihin kurbanlarının bakış açısından olmalıdır ve metot da tümevarım olmalıdır. Bilgi, problem analizi ve çözüm arayışları yerli gruplardan, otonom kök örgütlerden, yoksulluk, eşitsizlik, zulüm ve suistimale maruz kalmış olanları içeren sosyal hareketlerden gelmelidir (Litonjua, 2012, s. 46). Planlama, programlama ve politika araçları ile müdahale şekilleri de gerçek ihtiyaç sahiplerini kalkındırmaya yönelik olmalıdır.

Kök organizasyonlar ve örgütlerden başlanması düşüncesi de kurbanların bireyler değil toplumlar ve yerel birlikler olmasına neden olmuş ki, onların dayanışması ve güçlenmesi aslında özgürlüklerinin anahtarlarıdır. Burada en önemli hedef kalkınma söyleminin özneleri ile nesnelerinin yerlerinin değiştirmektir. Başka önemli olan bir husus da kamu yardımları, hibeleri ve programlarından yararlananların gerçekten yerli ve ilerici sosyal hareketlerin sadece yararlanmaya çalışan menfaatçilerden ayrıştırılmaları hususudur. $\mathrm{Bu}$ nedenle de yoksulluk ve düşkünlüğün kök nedenlerine inebilmek için insanların yaşamları ve geçimleri ile ihtiyaç ve geleceklerine odaklanılmalıdır. İnsanların çektikleri adaletsizlik ve yoksulluk kişisel değil, toplumlarının her alanında inşa edilmiş ve onların değer yargıları ile davranışlarından beslendiğinden dolayı küresel sosyo-politik sistemden beslenen yapısal ve kültürel köklere dayanmaktadır. (Litonjua, 2012, s. 46).

$\mathrm{Bu}$ noktada dikkat edilmesi gereken husus, küresel ölçekte örgütlemiş ve salt anlamda merkez kapitalist ülkelerin çıkarlarını koruyan çıkar grupları ile işbirlikçilerine hizmet edilmemesidir. Buradaki paradoks, gelişmekte olan veya gelişmemiş toplumların kendi çözümlerini ortaya koymada gerekli yetkinliği ve uygulama otoritesini sağlayamamasından dolayı her halükarda merkez kapitalist ülkelerin politik ve ekonomik güç alanının çevresinde konumlandıklarından dolayı kurumsal yapılanmalar ve yeni politika uygulamalarında büyük sermayedarlar ve kapitalist kompradorların çıkarlarının gerçekleştirilmesinin kaçınılmazlığında ve buna karşı konulmasının zorluğunda ortaya çıkmaktadır.

Türkiye'de bölgesel kalkınma ajansları (KA) çerçevesinde bakıldığında birer kök organizasyon işlevi görebilecekleri, değişimi tetikleyen katalist niteliğinde uygulamalar yapabilecekleri ve bu sayede bölgesel potansiyelleri ortaya çıkararak yerel dinamikleri harekete geçirmelerinin olanaklı olup olmadığ belirleme tek başına değişimi istenilen ölçüde sağlayabilmeyi temin etmez. Merkezi hükümet ve yerel kilit aktörler üzerinde sermaye grupları ve belirli güç odakları etkili olabildikleri için verilen hibeler ve desteklenen projeler de bu gerçeklikten azade bir şekilde ideal olarak bölgesel kalkınma hedeflerine hizmet etmeyebilir. DDK tarafından bölgesel kalkınma dinamiklerindeki sorunlar olarak belirlenen 43 adet problemin çözülebilmesi de merkezi, bölgesel ve yerel ekosistem, paydaşların ilişkileri, yönetişim mekanizmasının etkinliği ve hukuk devleti normlarının uygulanabilirliğiyle yakından ilişkili olacaktır.

\subsection{Sürdürülebilir Topluluklar}

Sürdürülebilirlik yönetimi, her nasılsa çevresel, sosyal, ekonomik ve politik ilişkilerin temelde sorgulanarak bu ilişkileri biçimlendiren ve servetin ve firsatların nesiller ve toplumlar arasından adil dağılımını sağlayan adalet, saygı, eşitlik, idare, tedbir ve geleceği gözeten temel ilkelerle perçinleşmiş politika ve uygulamaları yansıtması gerekir. (Huber \& Angel, 1996, s. 132)

Kalkınma amacıyla doğanın tahrip edilmesi, kaynakların gelecek nesillerin ihtiyaçlarını tehlikeye atacak şekilde müsrifçe kullanılması, sağlık sorunlarına yol açacak kanserojen madde kullanılması gibi pek çok husus günümüzde sürdürülebilirliği tehlikeye atan en temel hususlar olarak ortaya çıkmaktadır. Ancak az gelişmiş ülkeler için sürdürülebilirlik ile ilgili kural ve standartlara uyum üretim maliyetleri açısından bir artı külfet ve uluslararası ortamda ulus aşırı şirketlere ve merkez kapitalist ülkelerdeki kaliteli ürünlere göre rekabetçilik açısından da eksi bir zayıflık olarak ortaya çıkmaktadır.

Kalkınma her ne kadar niceliksel değerler kadar niteliksel ve öznel değerleri de içeriyorsa da aslında ekonomik büyüme, kalkınmanın başlangıcı, tetikleyicisi ve sonudur. Modernleşme teorisinin hedefi geleneksel toplumları modern uluslar haline getirmek idi ve bunun en son aşaması da yukarıda belirtildiği gibi "kitlesel tüketim" aşamasıdır. "kalkınma söylemi" kuramına göre kalkınmacılar, bu hedefe ulaşamadı ve asla ulaşamayacaktır. Kalkınma teorisinin, planlarının, politikalarının ve uygulamalarının sonuçları son elli yıl ve daha fazlasında herkes için iyileşme sağladı fakat servet ve gücün adaletsiz dağılımı ki bunda bir kaçı yararlanırken geriye kalanı bataklıktaki sefaletle gerilemiştir (Litonjua, 2012, s. 46).

Kalkınma modeli, gelişmiş batı ülkelerinin doyumsuz pazar ve kaynak ihtiyaçlarının jeopolitik tatmini için oluşturulduğundan dolayı, gerçekten fakirin iyiliği için tasarlanmamıştır. Kalkınma modeli, fakir ülkeleri, uluslararası örgütler ve küresel şirketlerin diktasına dar bir 
itaat ve bağlılık ceketi içerisinde hapsetmektedir. Yerel paydaş ihtiyaçlarına göre kurumsal yapılanmaların ve kurumsal hedeflerin oluşturulması bu anlamda yenilikçi ve gelişmekte olan ekonomilerin kendi dinamiklerine göre kalkınma politikaları ve kurumsal yapılanmalarına olanak tanımaktadır.

Litonjua'ya göre, Çin, şimdi kısmen yoksulluğun belini kırarak önceki koloni sahipleriyle aynı hizada durmaya çalışmakta ve Hindistan da onu takip etmeye çalışmaktadır. Sürdürülebilir topluluk ekonomilerinin oluşturulması için aşağıdaki dört noktaya önem verilmesi gerekir (Litonjua, 2012, s. 47-48):

1. Yerel ekonomik topluluklar ancak küresel ekonomiyle entegre olabildikleri ve paylaşılacak kekin parçası için yapacakları rekabette başarılı olabildikleri ölçüdedir. $\mathrm{Bu}$ nokta hem KA görevleri içerisinde hem de ulusal ve bölgesel kalkınma planlarında yer almaktadır. Ancak uygulama ile ilgili olarak neler yapılması gerektiği tartışmalıdır. Korumacılıkla ulusal ve bölgesel rekabetçiliğin güçlenemeyeceğini, sürekli devlet desteklerine dayanan ve kalitesiz mal ve hizmet üreten firmaların uluslararası rekabetle tanışarak kendilerini güçlendirme imkânı bulmaları gerektiğini savunanlar olmakla birlikte her halükarda ve en azından tarife dişı engellerle yıkıcı rekabete karşı mutlaka yerli sektörün korunması gerektiğini aksi takdirde uluslararası ölçek ekonomilerine sahip firmalara karşı yenilmek durumunda kalacaklarını savunanlar da vardır.

2. Yerel teşkilatlar için detaylı bir "ihtiyaç haritası" çizmek, yerel insanların kendi kalkınma hedefleri ile ilgili zihniyetleri ve anlayışlarını yükselten bir bölgesel planlama süreci işletmek gerekir. İhtiyaç haritalarının çıkarılması kolay değildir. Her sektörde zafiyetlerin, kırılganlıkların, potansiyellerin ve güçlü yönlerin tespit edilebilmesi olanaklı olmasına rağmen temel ihtiyaç nedir ve en uygun tedbir ne olmalıdır gibi sorulara verilen cevapların objektif ve gerçek ihtiyacı yansıtabilmesi zordur. Doğru bilginin mevcut olmaması, sistematik veri toplama ve analiz etme yetkinliğinin sürdürülebilir bir düzeyde olmayışı, veriler ve bilgi üzerinden güçlü olanların veya karar mekanizmalarına yakın olanların çıkarları doğrultusunda ihtiyaç tespitlerinin yanlı olarak yapılmasına da neden olabilir.

3. Yerel teşkilatların sosyal, fiziksel, beşeri yönden "varlık haritaları" çizilmeli, bu varlıkların ekonomik üretkenliğinin, çoklu ekolojileri yansıtmaları sağlanmalı, verme, paylaşma, borçlanma, gönüllü olma, karşılıklı bireysel ve kolektif çalışmaları gelenekselleştirmelidir. Varlık haritalarını çıkarılması da kolay değildir. Bunun kim tarafından nasıl çıkarılacağı, hangi periyotlarla güncelleneceği ve doğru bilginin elde edilip edilemeyeceği gibi hususlar temel zorlukları teşkil eder. Gelişmekte olan ülkelerde kayıt dışı ekonominin \%50 civarında olması firmaların bilgi paylaşımında dürüst olmamalarına neden olduğundan dolayı varlık haritaları ile ihtiyaç belirlemenin yapılması büyük bir handikap olarak ortaya çıkmaktadır. Gelişmiş batı ülkelerinde ise her şey sistem dahilinde olduğundan dolayı varlık haritaları ve ihtiyaç belirleme işi birkaç online anketle bile kolaylıkla yapılan ve zaten belirli bir departmanın rutin işleri olarak gerçekleştirilebilmektedir.

4. Yaşam standartlarını yükseltmek için geleneksel uygulamalar tekrar yönlendirilmeli, gönüllü çalışmalar teşvik edilerek toplumun orta ve uzun vadeli geleceğine yönelik yatırımlar için ciddi finansal imkân sağlanmalıdır. Gönüllü çalışabilmek için belirli bir gelir düzeyinin üzerine çıkmak ve vaktini geçirmek için aktivite arayışı içerisinde olanların hatırı sayılır bir sayıya ulaşmalarını gerektirir ki bu yönden organizasyonlar sistematik olarak yapilabilsin. Az gelişmiş ülkelerde bu anlamda gönüllü organizasyonlarla yaşam standardını yükseltilebilmesi olanakl1 olabilse bile denetim ve kontrol mekanizmalarının zayıflığından dolayı art niyetli veya belirli çıkarlar peşinde koşan kimselere faaliyet alanı açılması gibi handikapları doğurabilmektedir.

Yukarıdaki hususlar karşılaştırmalı olarak detaylı bir şekilde incelendiğinde Türkiye'de beş yıllık kalkınma planı (BYKP), bölgesel gelişme ulusal stratejisi (BGUS) ve bölge kalkınma planı (BKP) öncelik ve eylemleri kapsamında değerlendirilebilen paralel hususlar olduğu görülecektir. Dolayısıyla sürdürülebilir topluluk açısından bölgesel kalkınmanın "kök organizasyonu" olabilen KA önemli bir aktör olabilir. Bu nedenle KA, işleyiş sistemini, plan ve politikaları ile müdahale araçlarını ve süreçlerini paydaş ihtiyaçlarına göre yapılandırması önem arz etmektedir. Bu da ulusal, bölgesel ve yerel ihtiyaç ve çıkarlara hizmet etme yetkinliğinin sağlanmasıyla elde edilebilir.

Merkez kapitalist ülkelerin ekonomik ve toplumsal gerçekliklerinin bir doğal sonucu olarak ortaya çıkan ve sürekli gelişen bilginin ürettiği teori ve kavramlar bazen gelişmekte olan bir ülkenin anlayışları ve kavrayışlarına uygun düşmeyebilmekte ve anlaşılması zorlaşmaktadır. $\mathrm{Bu}$ nedenle de öncelikle iç ve dış paydaşların ihtiyaçları belirlenmeli ve bu ihtiyaçları gidermeye yönelik kurumsal yapılanma ve hedefler belirlenmelidir. Gerçek ihtiyaç her zaman hibe vermek ya da doğrudan yenilikçi ve rekabetçi olmalarının beklenmesi şeklinde olmayabilir. Yani küresel rekabete karşı dayanamayarak zayıflama veya gerileme riskleriyle karşı karşıya olan bebek endüstrisi düzeyindeki sektörlerin korumaya alınmadan neoliberal uygulamaların doğrudan benimsenmesi uygulamada telafisi güç sonuçlar doğurabilir. Bunun yanı sıra kamusal kaynaklı hibelerden beslenen, rekabete cesaret etmediğinden veya sübvanse edici ekosisteme bağımlılığı kar maksimizasyonu çerçevesinde realize etmeye çalışan, politik nepotizm üzerinden ekonomik değer üretebilen ve sürekli bakıma muhtaç sektörlere karşı önlem alınması gerekliliği de ayrı bir husus olarak dikkate alınmalıdır. Aksi durumda merkez kapitalist ülkelerde üretilen ve oradaki dinamiklerin ihtiyaçlarını karşılamaya yönelik olan tüm yeni-neo-post paradigmalar gelişmekte olan ülkelerdeki sorunların çözülmesine olanak sağlamayacaktır.

\section{Sonuc}

Modernleşme ile birlikte başlayan kalkınmacılık sürecinde pek çok uluslararası program ve proje başarısız olmuştur. Gelişmiş batı ile az gelişmiş dünya arasındaki gelir farkı giderek kapanması amaciyla uygulanan kalkınma programları ve refah devleti amaçlı keynezyen harcamacı 
maliye politikaları sonucunda az gelişmiş ülkelerde bir talep artışına yol açmış ise de bu gelişmiş ülkelerin ürünlerini satılmasını, şirketlerinin daha çok iş almasını ve dolayısıyla rekabetçilikleri ve üstünlüklerine güç katmıştır. $\mathrm{Bu}$ söylemin ampirik olarak ispatlandığ 1 bilindiğinden dolayı bağımlılık teorisine (dependency theory) dayanan post kalkınmacilık (post-development) teorisi de "kalkınmacı söyleme hayır" şeklinde bir yaklaşım sergilemiştir.

Bağımlılık teorisi, uygulanan kapitalist programlarla kaynakların fakir ve az gelişmiş devletlerin "çevresinden" zengin devletlerin "merkezine" aktığı ve ikincisini birincisi pahasına zenginleştirdiği fikridir. Teori, modernleşme teorisine bir tepki olarak ortaya çıktı, daha önceki geleneksel bir kalkınma teorisi, tüm toplumların benzer gelişim aşamalarında ilerlediğini, dolayısıyla günümüzün az gelişmiş bölgelerinin de geçmişte bir zamanda bugünün gelişmiş alanlarına benzer bir durumda olduğunu, ve bu nedenle, azgelişmiş alanlara yoksulluktan kurtularak müreffeh olma görevi, yatırım, teknoloji transferleri ve dünya pazarına daha yakın entegrasyon gibi çeşitli yollarla bu sözüm ona ortak gelişme yolunda onları hızlandıracağı savunulmaktır. Bağımlılık teorisi, az gelişmiş ülkelerin yalnızca gelişmiş ülkelerin ilkel versiyonları olmadıklarını, kendilerine özgü özellikleri ve yapıları olduğunu savunarak bu görüşü reddetmiş ve daha da önemlisi, batı tarzı kalkınma modeli uygulayanların bir dünya piyasa ekonomisinin daha zayıf üyeleri olma durumunda olacağını savunmuştur.

Küreselleşme ile birlikte gelişen politik süreçler, BM, IMF ve $A B$ tarafından önerilen yeni sağ politikalarla kamusal özün giderek kaybolduğu ve Anayasa'daki idarenin bütünlüğü ilkesine aykırı olan KA yapılanmasının da yeni bir tür merkezileşme anlayışına hizmet ettiği noktasında önemli endişeler de mevcuttur. $\mathrm{Bu}$ konuda, Karasu tarafindan yapılan bir çalışmada şu ifadelere yer verilmektedir: "Yeni tür merkezileşme ve onun kurumsallaşması, devletin merkezi ve yerel parçaları arasında tamamlayıcılık esasına dayalı işbölümünü, merkezi planlama ve idarenin bütünlügünü sağlayacak mekanizmalar ile kamu hizmetlerini ülkenin her yanında eşit bir biçimde örgütlendirilmesini öngören ulusal planlama ve kalkınma esasına dayanan merkezileşme biçiminden farklılaşmaktadır." (Karasu, 2009, s. 31)

Yerel ve bölgesel kalkınmanın tanımları ekonomik ve sosyal, çevresel, politik ve kültürel kaygıları da içerecek şekilde genişletilmiştir. Tanımlar, coğrafi farklılaşma ve zaman içindeki değişiklikleri içeren, tarihsel olarak kalıcı temalar, ilkeler, kültürel-dini unsurlar ve değerler bağlamında toplumsal olarak belirlenebilmektedir. Coğrafya ve jeopolitik, yerel ve bölgesel kalkınmada nedensel faktörler kapsamında önemlidir. Bölgeler, yerel ve bölgesel kalkınmanın belirli tanımlarının inşa edildiği ve takip edildiği tanımlanmış alanlar olarak gelişir. Yerler, coğrafi çeşitliliği, eşitsizliği ve yerel ve bölgesel kalkınmanın bağlamını şekillendirir. Ekonomik, sosyal, politik, çevresel ve kültürel süreçler, farklı ölçekler arasında ve boyunca yerel ve bölgesel kalkınmayı etkiler. Farklı yerel ve bölgesel gelişme türleri, coğrafi olarak farklılık gösteren ve zamanla değișen sosyal olarak belirlenmiş ve normatif ilkeler ve değerlerle bağlantılıdır.
2006 yılından sonra mevzuatı hazırlanan ve fiilen 2009 yılından sonra Türkiye'de Nuts-II sinıflandırma mekanizmasına göre yeniden tanımlanan 26 bölge suni olarak teşkil edilerek temelde bölgelerarası dengesizlikleri azaltmak, yatırım çekerek yerel ve bölgesel dinamikleri harekete geçirecek olan kalkınma ajansları kurulmuştur. Ancak onbinlerce projeye finansman sağlanırken KA tarafından gelir, istihdam ve ihracat üzerinde ciddi bir etkinin kayda geçirilemediği anlaşılmaktadır. Kalkınma Bakanlığının lağvedilerek KA koordinasyon ve denetiminin Sanayi ve Teknoloji Bakanlığına devredildiği 2018 yılından itibaren de yeni merkeziyetçi bir akım ile yerel ve bölgesel yönetişim mekanizmalarının etkisiz ve işlevsiz kaldığı önemli uygulama ve programlar ile bazı projelerin merkezi talimat ve yönlendirmelerle hayata geçirilebildiği gözlemlenmektedir. $\mathrm{Bu}$ da yeni bölgeselciliğin de krize girdiğinin işareti olarak değerlendirilebilir.

Araştırma sorularımıza aşağıdaki şekilde cevap verilebilmektedir:

Post Kalkınmacılık (gelişme sonrası) teorisi günümüz kalkınmacılık dinamiklerindeki sorunlara çözüm getirme kabiliyetinde midir? Eksiklikleri var mı?

Klasik gelişime yaklaşımların başarısız olduğu ve Postmodernizm düşüncesinin yanı sıra doksanların başında birkaç yazar "gelişim döneminin sonunu" tartışmaya başladı. Gelişme fikri, entelektüel manzarada bir harabe gibi gösteriliyor. Gelişme sonrası teorisinde üç düzeyde eleştirilir: ilk olarak, siyasi bir proje olarak, ikinci olarak entelektüel bir yapı olarak ve üçüncü olarak da bir terimin kendisi olarak (Ziai, 2007).

$\mathrm{Bu}$ düşünceye göre, Batı Avrupa ve Kuzey Amerika endüstriyel kapitalizmi, diğer toplum veya toplum biçimlerinden daha değerlidir. Sonuç olarak, kalkınma projesinin emperyalist olduğu, kalkınma yapısının Avrupa merkezli olduğu saldırıya uğradığı, terimin kendisinin boş olduğu hipotezlerine dayanmaktadır.

Gelişme sonrası teorinin maddi olmayanlara olan vurgusu, bağımlılık (dependency) teorisiyle ilişkisi olmasından dolayıdır. Gelişme sonrası teorisi, Batı'nın kalkınmasının Üçüncü Dünya'nın sömürülmesine dayandığı inancında bağımlılık teorisini yansıtıyor, ancak bu sömürüyü maddi olarak vurgulamıyor, hatta sorunu çözme yolunu yalnızca maddi olarak vurgulamıyor. $\mathrm{Bu}$ anlamda alternatif bir metodoloji geliştirme noktasında eksik kalmaktadır. Belki de gelişme sonrası teorisinin en yaygın eleştirisi, eleştirmenlerin gelişme sonrası teorinin gelişime yeterli bir alternatif sağlamadığı duygusuyla ilgilidir. Eleştiriler arasında, gelişme sonrası teorisyenler tarafından sunulan alternatiflerin ayrıntılarının eksik olduğu, gerçekleşme ihtimalinin düşük olduğu ve sonuçta alternatif gelişme yaklaşımlarının sunduğu alternatiflerden daha az yapıcı olduğu yönünde bir eğilim vardır.

Gelişme sonrası teorisinin başka bir eleştirisi, gelişme sonrası teorinin etiği ve politikasına odaklanır. Gelişme teorisinin birçok eleştirmenine göre, gelişme nihayetinde, dünyamızda ortaya çıkan korkunç eşitsizliklerin durumundan az gelişmiş olanları serbest bırakarak ele almakla ilgilidir. 
Post kalkınmacılı teorisiyle KA ve bölgesel kalkınma sorunları çözülebilir mi?

Keynezyen uygulamalara karşı olan Postkalkınmacı yaklaşımla kalkınmacı uygulamaların terkedilmesi gerektiği için bu yaklaşımla KA ve bölgesel kalkınma sorunlarının çözülebilmesi olanaklı görülmemektedir. Her halükarda mevcut kalkınmacı kurumlar, politikalar ve uygulamalar veri alınarak ulusal, bölgesel ve yerel ihtiyaçlara ne derece hizmet edip edemeyeceğinin analiz edilmesi gerekir. BM tarafından öngörülen "yönetişim mekanizmaları" gibi ithale dayalı anlayışlar uygulamada karşılık göremediği gibi bu tür anlayışlara karşı direnç noktalarının da meydana gelmesine yol açabilmektedir. Örneğin yönetim kurulları ile kalkınma kurulları yerel ve bölgesel yönetişim mekanizmalarının ana unsurları iken sunuluş şekli ve sonradan öngörülen yukarıdan inmeci ulus devlet ayarları yüzünden işlevsiz hale gelebilmektedirler. Halbuki İslam geleneğinde danışma, meşveret, rıza ve dayanışma çok yoğun olarak mevcut iken yönetişimin batı tarafından empoze edildiği ve aslında bizim iç dinamiklerimize uygun olmadığı noktasındaki mülahazalar doğru değildir.

Merkez kapitalist ülkelerdeki toplumsal ve yönetsel koşullara uygun kurumsal yapılanmalar ve uygulamaların doğrudan transfer edilmesi kamu kaynaklarının israf edilmesine yol açabildiği gibi buna göre kurulmuş kurumları ve uygulamaları tek kalemde kaldırmak yerine elde edilen tecrübelerle aksayan yönleri düzeltmek ve ulusal ve yerel çıkarlara hizmet edecek şekilde yeniden düzenlemek en doğru olanıdır. KA yapılanması da buna en önemli bir örnek olup, 43 sorun üzerinden DDK tarafindan yapılan tespitler ve önerilere karşılık hazırlanan eylem planının detaylandırılarak olabildiğince uygulanabilir değişiklikleri yapmak en doğrusudur. Bunun için de daha önce KB tarafindan hazırlanan eylem planının, en son Sayıştay Raporu önerileri de dikkate alınarak, KA koordinasyonundan sorumlu olan Sanayi ve Teknoloji Bakanlığı (STB) tarafından kısa-orta-uzun şeklinde vadelere ayrılarak uygulamaların detaylandırılması ve takip edilmesi gerekir.

Burada uygulanacak metodoloji ise öncelikle gerekli mevzuat alt yapısının bölgesel aktörleri öncülleyen ve onları teşvik eden bir niteliğe kavuşturulması yanı sıra, bölgesel kalkınma için gerekli olan ekosistem ve sosyolojik tabanlarının güçlendirilmesi, paydaşlar arasından iletişimin yoğunlaşmasını ve anlayışların yakınsamasını sağlayacak yumuşak önlemlere öncelik verilmelidir. $\mathrm{Bu}$ da büyük ölçüde profesyonel yetkinlikleriyle ön plana çıkmayan, makam hırsı ve şahsi çıkarlarını öncülleyen kifayetsiz muhteris yöneticilerin tasfiye edilerek ehliyet, liyakat, yarışma, performans ve erdeme göre temayüz ederek atanabilmeyi kolaylaştıracak mekanizmaların kurumsallaştırılmasıyla olanaklıdır.

\section{Kaynakça}

Andrews, N., \& Bawa, S. (2014). A Post-development Hoax? (Re)-examining the Past, Present and Future of Development Studies. Third World Quarterly, 922-938.
Arslan, E. (2010). Kalkınma Ajanslarl ve Kalkınma Ajanslarının Türkiye Ekonomisine Beklenen Katkıları. Konya: Selçuk Üniversitesi İktisat ABD basılmamış Doktora tezi.

Aslan, O. E. (2006). Kamu Personel Rejimi ve Anayasal Ilkeler. Ankara: TODAİE Yayını, .

Bartling, H. (2004). Organizing the New South: Local Ecologies and Autonomous Strategies for Confronting Globalization. Mississippi Quarterly, 135-145.

Blanco, I. (2015). Between democratic network governance and neoliberalism: A regime-theoretical analysis of collaboration in Barcelona. Cities, Volume 44, 123 130 .

Brigg, M. (2002). Post-development, Foucault and the colonisation metaphor. Third World Quarterly, Vol 23, No 3, 421-436.

DDK, Aykın, H., ARSLANBAŞ, M., DERE, A., ÖZÇELIK, A., BOYALI, C., . . . ÖZKILINÇ, M. A. (2014). Kalkınma Ajansları Inceleme ve Araştırma Raporu (Hizmete Özel). Ankara: Cumhurbaşkanlığı Devlet Denetleme Kurulu, http://www.tccb.gov.tr/faaliyetler/ddkraporlari/.

Dobren'kov, V. I., \& Rakhmanov, A. B. (2014). Center and Periphery. Value Inquiry Book Series, Vol. 276, 5151.

Efe, A. (2015). Türkiye'de Kalkınma Ajanslarl için Bir Yönetişim Modellemesi: COBIT-5. Ankara: TODAİE (Basılmamış Doktora Tezi).

Efe, A. (2016). Kalkınmacılıkta Temel Riskler ve Çözümler. Saarbrücken: LAB LAMBERT Academic Publishing.

Efe, A. (2016b). Türk Kamu Yönetimi İçin Yenilikçi Bir Yönetişim Modeli. Saarbrücken: LAB LAMBERT Academic Publishing.

GRAAFF, J. (2006). The Seductions of Determinism in Development Theory: Foucault's functionalism. Third World Quarterly, Vol. 27, No. 8, $1387-1400$.

Huber, J., \& Angel, D. P. (1996). Building Sustainable Industries For Sustainable Societies. Business Strategy \& the Environment, 127-136.

Karasu, K. (2009). Yerelleşme Söylemi Ve Bölge Kalkınma Ajansları. Memleket SiyasetYönetim, Cilt: 4, Sayl: 11, , 1-43.

KB-BGYUGM. (2014). Devlet Denetleme Kurulu Kalkınma Ajansları Araştırma Ve İnceleme Raporu Kapsamında Alınacak Tedbirler . Ankara: Kalkınma Bakanlığı (hizmete özel).

Kuhn, T. (1962). the structure of scientific revoluiton. Chicago, USA: University of Chicago.

Lie, J. H. (2008). Post-Development Theory and the Discourse-Agency Conundrum. Social Analysis, Volume 52, Issue 3, 118-137.

Litonjua, M. (2012). Third World/Global South: From Modernization, To Dependency/Liberation, To 
Postdevelopment. Journal of Third World Studies, Vol. XXIX, No. I, 25-58.

Öztürk, A. (2009). Homojen ve Fonksiyonel Bölgelerin Tespiti ve Türkiye için Istatistiki Bölge Birimleri Önerisi. Devlet Planlama Teşkilatı Uzmanlık Tezleri Yayın 2802: esk.dpt.gov.tr/PortalDesign/PortalControls/WebIceri kGosterim.aspx?Enc=83D5A6FF03C7B4FCE4F4B E79F81E46F3 adresinden alınmıştır (17.10.2019)

Rapley, J. (2004). Development studies and the postdevelopment critique. Progress in Development Studies 4,4, 350-354.
Yılmaz, B. (2011). Kalkınma politikalarında değişim: bölgesel kalkınma ajansları. Sakarya: Sakarya Üniversitesi Kamu Yönetimi ABD Basılmamış Doktora Tezi.

Ziai, A. (2006): Zwischen Global Governance und PostDevelopment. Entwicklungspolitik aus diskursanalytischer Perspektive. Münster, Westfälisches Dampfboot. 